ISSN 2078-6441. Вісник Львівського університету. Серія географічна. 2018. Випуск 52. С. 79-88.

Visnyk of the Lviv University. Series Geography. 2018. Issue 52. P. 79-88.

http:/ / dx.doi.org/10.30970/vgg.2018.52.10171

911.3

\author{
рин удзеляк, рин ністрянськ \\ ьвівський н ціон льний університет імені в н \\ вул. . орошенк , 41, 79007, м. ввів, кр їн , \\ e-mail:ihudzelyak@gmail.com,i.dnistrjanska@gmail.com
}

ля сільської місцевості кр їни х р ктерні нег тивні демогр фічні тенденції, які в більшості обл стях поч ли виявлятися ще у 70 80-х рок х ст. і пов'яз ні, передусім, з депопуляційними процес ми. орсов н індустрі ліз ція т урб ніз ція спричинили мігр ційний відтік сільських жителів, який дод тково був зумовлений політикою ліквід ції хуторів т “неперспективних" сіл. е призвело до висн ження демогр фічного потенці лу, скорочення репродуктивних когорт, ст ріння н селення. йбільш гостро ці тенденції виявлялися в ернігівській, умській, олт вській, итомирській т иївській обл стях, де ще й природно-геогр фічні чинники не сприяли розширенню сільської поселенської мережі. еликий нег тивний вплив н відтворення людського потенці лу м в олодомор 19321933 рр. епопуляція сільського н селення кр їни відбув л ся т кож під впливом незб л нсов ного в просторовому спекті соці льного розвитку: через трив ле ст більне недофін нсув ння відбув вся з неп д медичної й освітньої сфери, інші г лузі соці льного обслуговув ння зовсім не відповід ли потреб м суч сного суспільств , що знижув ло серед молоді прив бливість сіл як місця постійного прожив ння. н чні мігр ційні втр ти, т кож зниження рівня н роджув ності визн чили тенденції швидшого, ніж у міст х, ст ріння сільського н селення. риродне відтворення сільського н селення м є звужений х р ктер і вирізняється поступовим зниженням н роджув ності, як ще з лиш ється вищою, ніж у міських поселеннях, високою смертністю головно через н дто деформов ну вікову структуру. риродний т мігр ційний рух сільського н селення визн чив дин міку сільської поселенської мережі: кількість поселень зменшується пр ктично в усіх обл стях кр їни, з винятком ьвівської, ернопільської, в но- р нківської, к рп тської, ернівецької, олинської т ерсонської. йбільше скорочення кількості сіл у олт вській, умській, ернігівській т іровогр дській обл стях. т біліз ція депопуляційних процесів у сільській місцевості можлив лише 3 умови ре ліз ції соці льної політики т ктивіз ції тих г лузей переробної промисловості, які пов'яз ні з гр рним сектором.

лючові слов : сільське н селення, сільські поселення, депопуляція, ст ріння н селення, природне відтворення, мігр ційний відтік.

емогр фічн криз , яку нині пережив є кр їн , і як особливо болісно виявляється в сільській місцевості, зумовлює небезпеки різкого посл блення сукупного соці льноекономічного, культурного і політичного потенці лу держ ви. одноч с н держ вному рівні відчутним є недост тнє розуміння як чинників т мех нізмів формув ння демогр фічної ситу ції, т к і відсутність декв тної держ вної політики в цій сфері. ьогодні, 3 умови інформ ційної війни, це ще й принципово в жлив геополітичн проблем , оскільки різні нтиукр їнські середовищ трив лий ч с н в'язув ли думк, що демогр фічну кризу в кр їні спричинило проголошення суверенітету в 1991 р., відт к

(C) удзеляк ., ністрянськ ., 2018 
розвиток усіх соці льно-економічних процесів періоду нез лежності. зн чимо, що природний приріст у сільській місцевості деяких регіонів ст в від'ємним з довго до н буття суверенітету держ вою, відповідно і кількість сільського н селення в цих регіон х поч л неухильно зменшув тися. іст влення д них про кількість сільського н селення кр їни в 1970 р. з д ними 1979 т 1989 рр. з свідчує, що с ме впродовж того ч су особливо стрімко поч л скорочув тися кількість сільського н селення кр їни. иняток ст новили лише к рп тськ, ернівецьк, ерсонськ обл сті т рим.

одішня $\mathrm{p}$ дянськ вл д пояснюв л т ку ст тистику мігр ціями н селення з міст до сіл і н зив л цей процес об'єктивною тенденцією. якби, процеси урб ніз ції того ч су не з зн ли форсув ння, м ли лише природний х р ктер, то не простежув лось би т ких диспропорцій у соці льно-віковій структурі н селення т різких регіон льних відмінностей, які спричинили в н ступний період одні з н йвищих у вропі темпи депопуляції н селення. тже, проблем визн чення чинників т передумов формув ння демогр фічної ситу ції в кр їні є в жливою як з соці льного, т к і з політичного поглядів.

ізні спекти демогр фічних проблем укр їнського сел дост тньо широко відобр жені в н уковій літер турі. $\quad$ к демічному рівні н йбільше досліджень провів нститут демогр фії т соці льних досліджень кр їни (. урило, . іб нов , . к ров , . тешенко, . еренько т ін.). гомі н укові пр ці, присвячені цій проблем тиці, н леж ть т кож . ог тько, . огожину т ін. їхніх публік ціях розкрито н с мперед соці льно-економічні спекти демогр фічної кризи в кр їні. одноч с м ловивченими є пит ння регіон льної диференці ції, виявлення передумов т мех нізмів депопуляції сільського н селення з з стосув нням порівняльного геогр фічного н лізу, що і є метою дослідження.

60 70-х рок х XX ст. н селення кр їни поступово перейшло від розширеного $\mathrm{x}$ р ктеру відтворення до простого, згодом - звуженого. роцес демогр фічного переходу до суч сного типу відтворення, який відбув вся у всіх кр їн х вропи, є одним з основних чинників скорочення н селення і м є природний х $\mathrm{p}$ ктер. роте тодішнє p дянське керівництво невмілою політикою т к скоригув ло демогр фічні процеси, що відр зу ст ли помітними дод ткові кризові ефекти. окрем , 3 50-х років ХХ ст. 3 політичних т економічних мотивів поч в проводити політику укрупнення сіл, згідно 3 якою м лі сел визн в ли “неперспективними”, прирівнюв ли до бриг д т позб вляли будь-якого фін нсув ння. цей же період більшість хуторів (поселень із кількістю жителів до 50 осіб) бул “припис н " до н йближчих сіл, решту ліквідовув ли, їхні мешк нці змушені були переселятися [7].

оловні принципи визн чення к тегорії перспективних і неперспективних сіл були сформульов ні в ухв леному резидією “ оложенні про порядок віднесення н селених пунктів до к тегорії міст, селищ міського типу і робітничих селищ (30 грудня 1956 р.) [5]. н слідок цієї укрупнюв льно-переселенської к мп нії, проведеної держ вою форсов но, із 58,5 тис. хуторів в кр їні н середину 60-х років 3 лишилося лише 8,4 тис. [7].

соці льно-демогр фічному контексті т к політик спричинил м совий відтік сільського н селення до міст. зн чимо, що сільське н селення перев жно орієнтув лося н н йбільші міст - иїв т рків. ктивіз ції прискореним мігр ціям н селення сприяло будівництво гідроелектрост нцій н ніпрі, що супроводжув лося підтопленням прибережних земель т, відповідно, переселенням місцевих жителів. йбільше сільські жителі мігрув ли в тих обл стях, де було визн чено н йбільше 
неперспективних сіл. ому н йвідчутніше т к політик відобр зил ся н демогр фічній ситу ції в ернігівській, умській, олт вській, итомирській т иївській обл стях. ричин ми поширення тут зн чної кількості м лих сіл є сукупність різних чинників. окрем , у природно-геогр фічному спекті порівняно невелик щільність поселень у зоні олісся зумовлен н явністю з болочених територій. ожн виділити й дві історико-політичні передумови: це столипінськ реформ, що сприял переселенню н селення північних т північно-східних обл стей у глибину осійської імперії, т кож м совий олодомор 19321933 рр., ун слідок якого н йбільших втр т з зн л иївськ , олт вськ, ерк ськ, итомирськ т інницьк обл сті [6].

имушен мігр ція сільського н селення вносил свої корективи в процеси демогр фічного переходу в кр їні: молодь, переїждж ючи до міст, поступово перейм л нову, м лодітну модель репродуктивної поведінки, переходил до звуженого типу відтворення, в сел х природний приріст знижув вся через зрост ння ч стки ст ршого н селення. сільській місцевості погіршув л ся соці льн ситу ція: зниження рівня медичного обслуговув ння підвищув ло смертність серед н селення, причому не лише серед осіб пенсійного віку, й серед пр цезд тних когорт і дітей. роцес відтоку селян до міст зумовлюв в дисб л нс віково-ст тевої структури сільського н селення. ому тр диції б г тодітності в укр їнських сел х нівелюв лися і не стримув ли депопуляційних процесів (рис. 1).

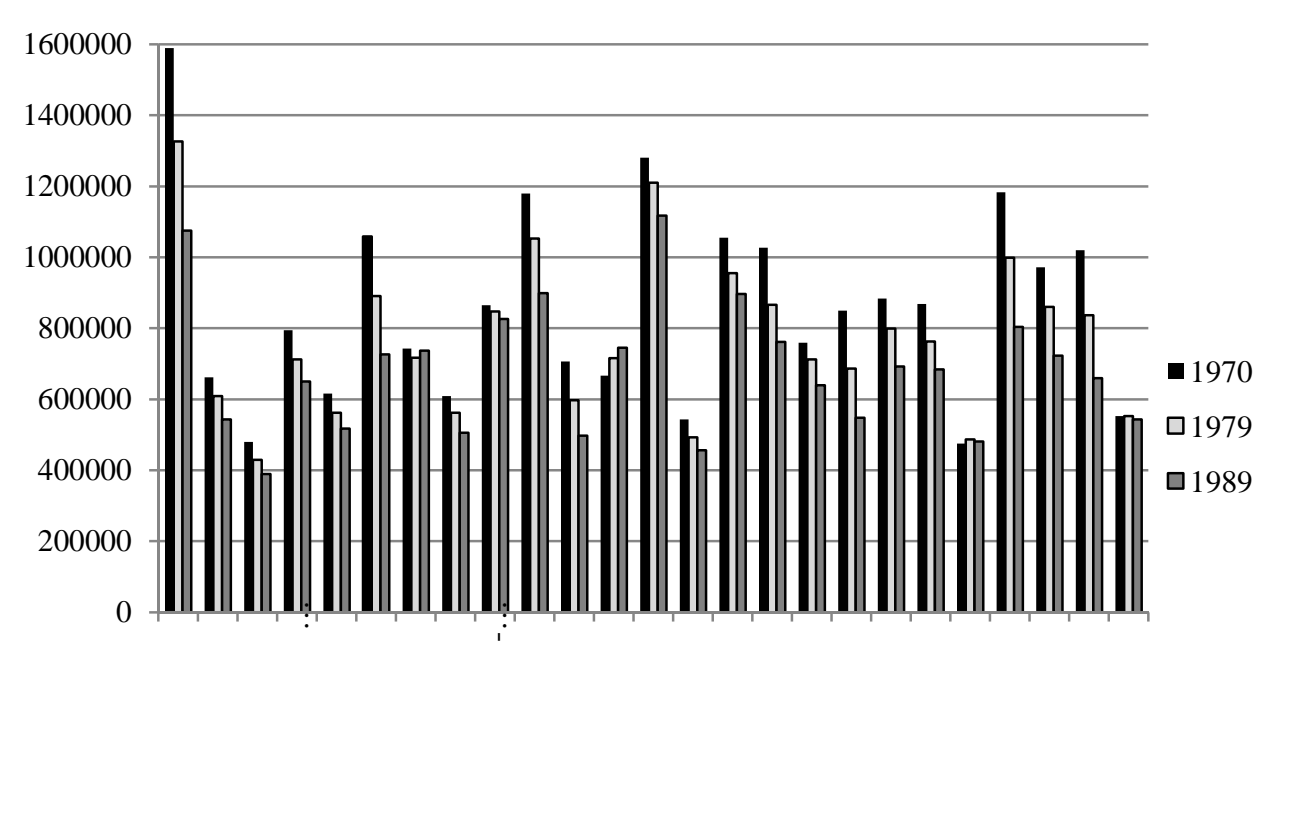

ис. 1. ин мік кількості сільського н селення регіонів кр їни (побудов но з [3-5])

Fig. 1. Dynamics of the rural population of the regions of Ukraine (based on [3-5])

ля визн чення суч сних регіон льних демогр фічних особливостей викон но порівняльний н ліз демогр фічної ситу ції в розрізі всього н селення т сільського 
зокрем . пок зник ми природного приросту (скорочення) особливо виділяється одн кризов обл сть - ернігівськ , 3 швидких темпів природного скорочення н селення в ерк ській, олт вській, умській, рківській, онецькій т порізькій обл стях (рис. 2). реб вр ховув ти, що усереднені зн чення коефіцієнт природного приросту в міських т сільських н селених пункт х не можуть повністю відобр зити демогр фічну кризу в деяких регіон х.

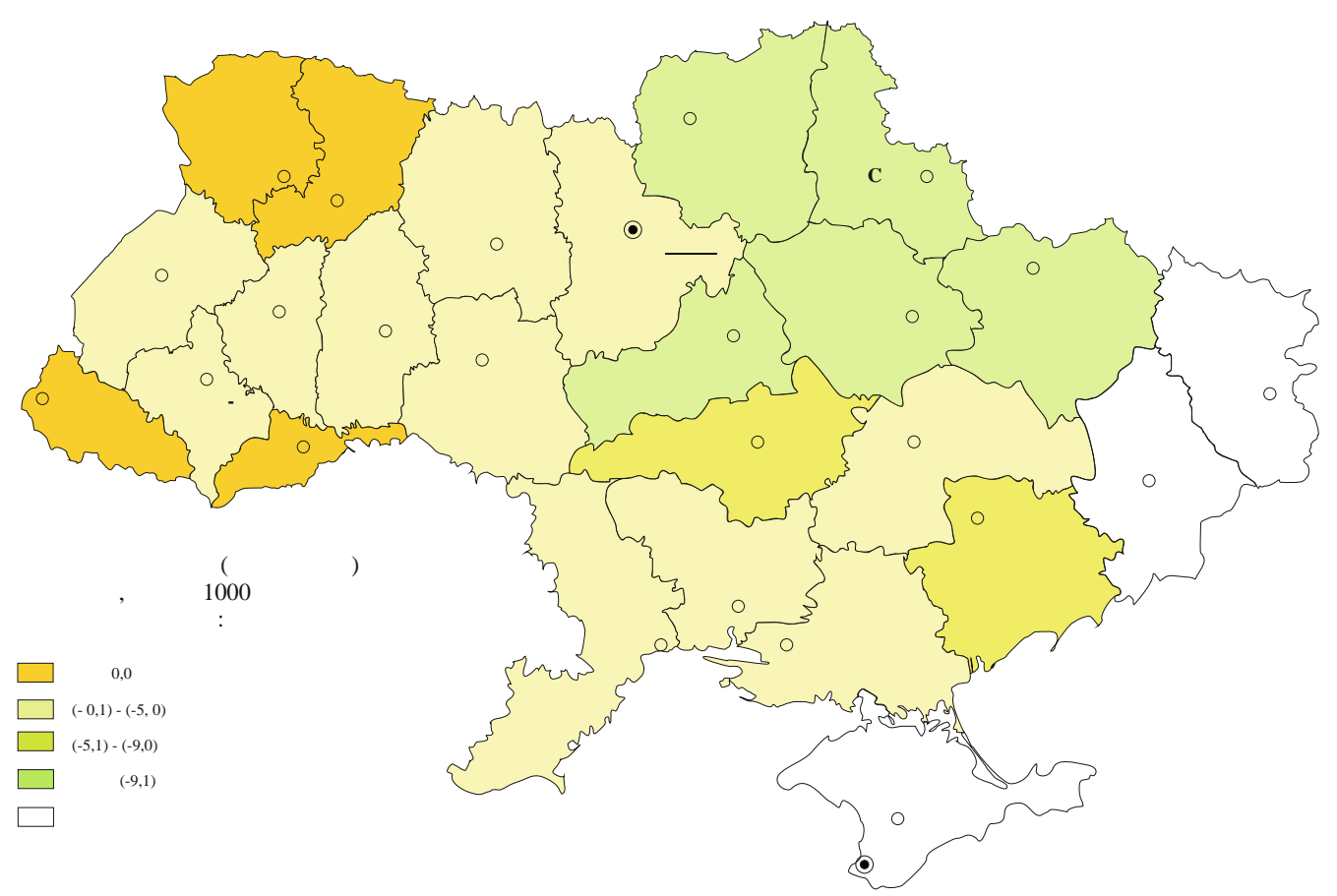

ис. 2. риродний приріст (скорочення) н селення кр їни, 2014 р. (побудов но 3 [9])

Fig. 2. Natural increase (decrease) of the population of Ukraine, 2014 (based on [9])

рис. 3, де пок з но природний приріст сільського н селення, чітко виокремлені дві обл сті ернігівськ т умськ, які ф ктично опинилися н межі демогр фічної к т строфи. лизькими до них 3 рівнем депопуляції сільського н селення $€$ иївськ т суміжні зі столичним регіоном олт вськ, итомирськ, інницьк, ерк ськ , мельницьк обл сті. одноч с у к рп тській т івненській обл стях зберіг ється дод тний природний приріст, зумовлений низкою чинників, н с мперед оптим льною віковою структурою н селення, збереженням сімейних тр дицій т більшою релігійністю н селення. к рп тській обл сті н відтворення сільського н селення вплив ють і деякі етнічні особливості, зокрем , високий природний приріст у середовищі ромського і румунського н селення. одібн ситу ція в інших з хідних обл стях ьвівській, ернівецькій т в но- $\mathrm{p}$ нківській. хоч тут простежується природне скорочення, проте 
порівняно з іншими обл стями кр їни не т ке зн чне, передусім, з вдяки помітно вищій н роджув ності. івень смертності в хідному регіоні $€$ нижчим, ніж в індустрі льних регіон х т північно-східних обл стях з високим рівнем ст ріння н селення.

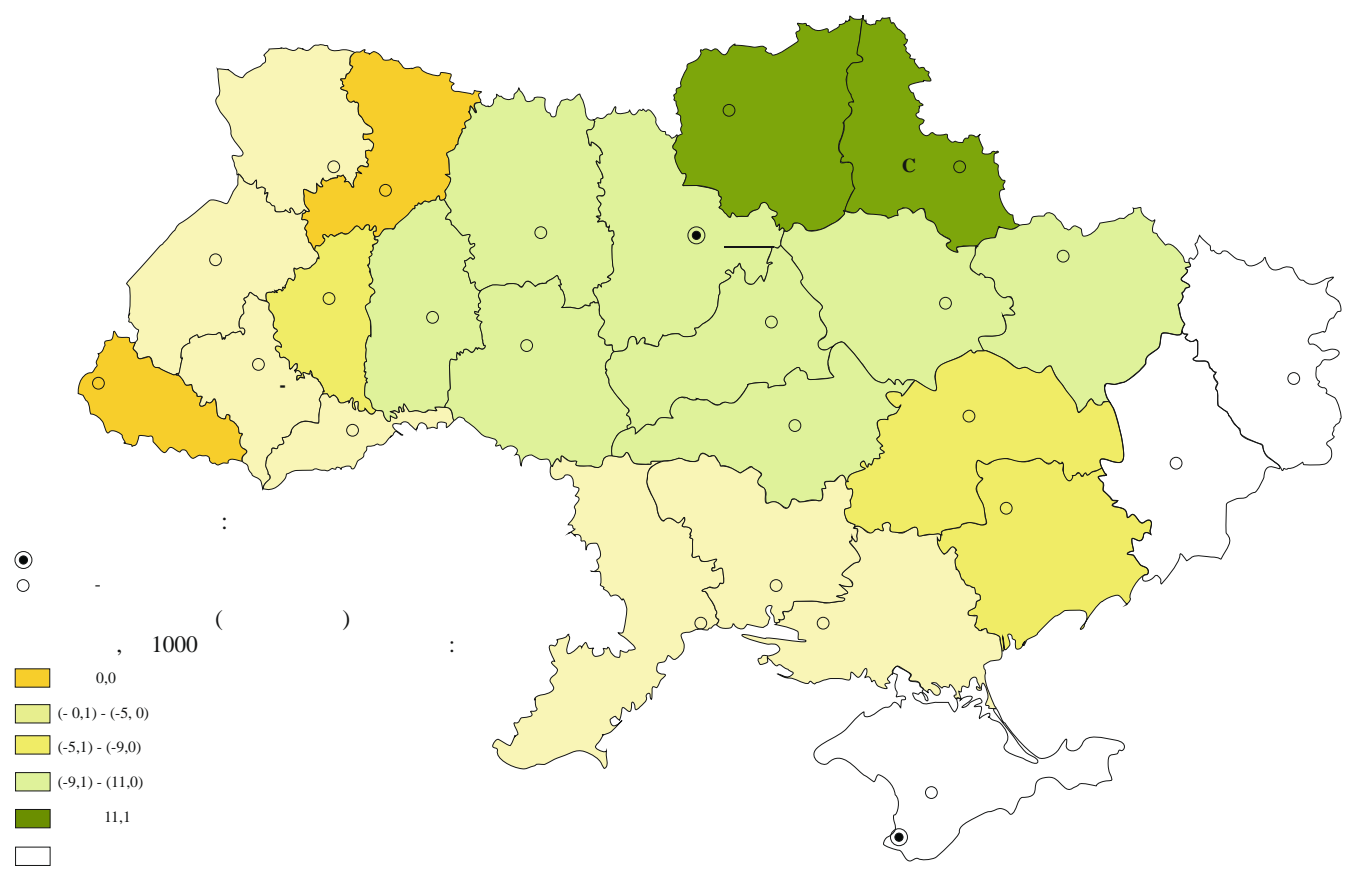

ис. 3. риродний приріст (скорочення) сільського н селення кр їни, 2014 р. (побудов но з [9])

Fig. 3. Natural increase (decrease) of the rural population of Ukraine, 2014 (based on [9])

ерев жно ліпшою, ніж у середньому по кр їні, є демогр фічн ситу ція в сільській місцевості південних обл стей ( деської, икол ївської, ерсонської), що пов'яз но з політикою з охочення переселення молоді в м лоз селені степові р йони, яку проводили впродовж 70-х років минулого

ст.

слідком демогр фічної кризи в сільській місцевості кр їни є з неп д і н віть повне зникнення сільських н селених пунктів (див. рис. 4). ізний рівень н роджув ності, передч сної смертності т мігр ційних втр т людей пр цезд тного віку визн ч ють тенденції формув ння вікового скл ду: диференці ція пок зник ст ріння сільського н селення з регіон ми поглиблюється. Г льноукр їнські д ні не відобр ж ють суттєвих відмінностей середнього віку сільського і міського н селення: середній вік міського жителя ст новить 40,7 років, сільського - 40,8 років. , якщо про н лізув ти вікову структуру н селення з обл стями, то можн виявити великі відмінності (див. рис. 5).

прикл д, середній вік сільського н селення ернігівщини - 46,5 років, умщини 44,5 років. Зн чн відмінність між середнім віком чоловіків т жінок: середній вік чоловічого н селення ернігівської обл. - 42,1 років, жіночого - 50,2 років, умської 40,9 т 47,6 років відповідно [9]. обл стях зі сприятливішою демогр фічною ситу цією різниця між середнім віком жіночого т чоловічого н селення не т к різк . 
ля н лізу демогр фічної ситу ції т кож в жливо вр хув ти впливи попередніх поколінь. суч сному ет пі темпи депопуляції скоротилися через входження в дітородний вік н селення 80-х років, коли р дянськ вл д вперше 3 пров дил окремі 3 ходи демогр фічної політики й поч л н д в ти деякі соці льні пільги молодим сім'ям. к політик стимулюв л н роджув ність, проте вон не спинил існуючі демогр фічні т мігр ційні процеси. годом н роджув ність поч л зменшув тися, н йнижчий рівень з фіксов ний у 2001 р., коли сум рний коефіцієнт н роджув ності знизився до 1,1 особи н одну жінку з весь репродуктивний період [1].

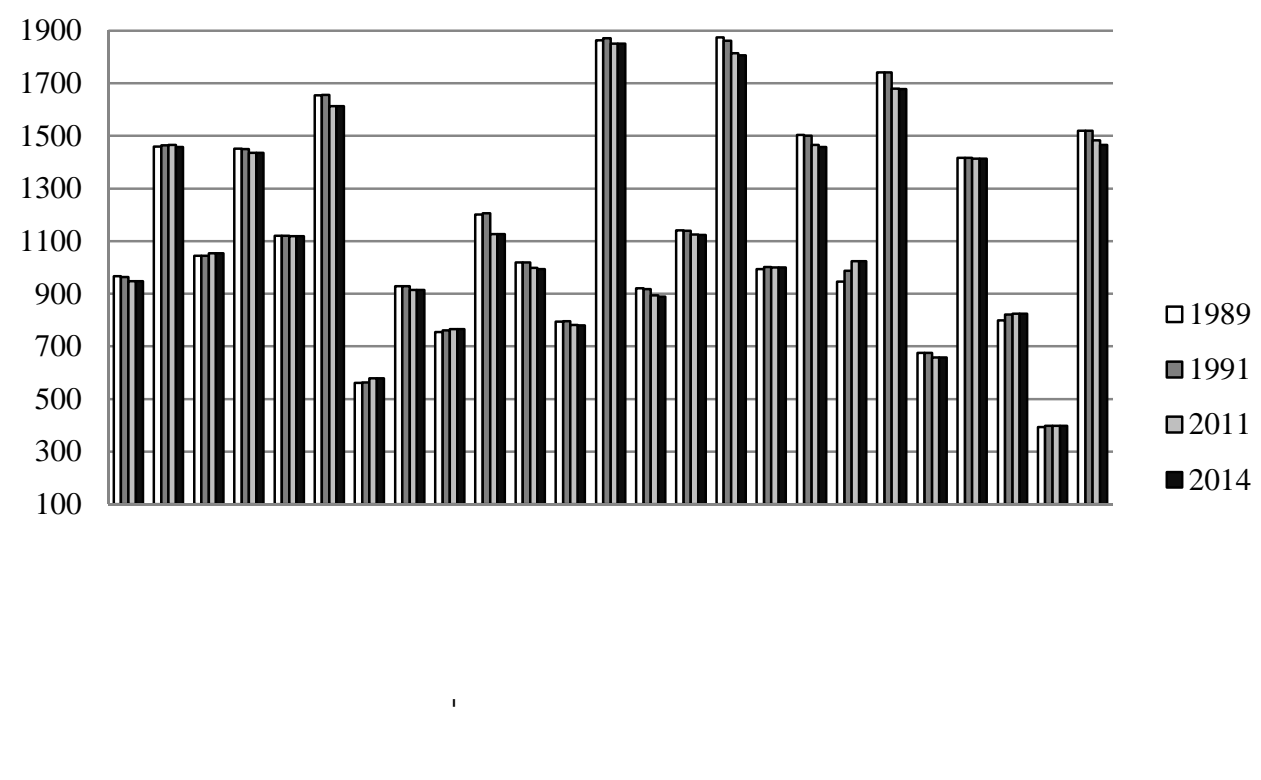

ис. 4. ин мік кількості сільських поселень регіонів кр їни (побудов но з [9])

Fig. 4. Dynamics of the rural settlements quantity in the regions of Ukraine (based on [9])

огляду н ретроспективні демогр фічні тенденції в 20202025 рр., коли в дітородну ф зу ввійде покоління 2001 р., н н ш погляд, ст тистик буде ще більш невтішною, оскільки економічний т соці льний з неп д укр їнського сел посилюється і мігр ції молоді до міст зрост ють. одноч с ч стк людей похилого віку постійно збільшув тиметься, що суттєво позн читься н економічному н в нт женні пр цезд тного н селення т знижув тиме пр цересурсний потенці л держ ви. Зн чимо, що ч стк ст ршого н селення в сільській місцевості зрост $є$ не 3 вдяки збільшенню кількості довгожителів, як у європейських кр їн х, через зменшення н роджув ності. исб л нс у ст тево-віковій структурі - це ще і з гроз зрост нню с мотності серед н селення, звідси - низк соці льних проблем, що їх змушені вирішув ти держ в бо регіон льн вл д .

тже, демогр фічн криз в сільській місцевості безпосередньо вплив $€$ н соці льно-економічну ситу цію в держ ві. ому нині як ніколи в жливо проводити ефективну регіон льну демогр фічну політику в обл стях з кризовими демогр фічними 
пок зник ми. ирішити демогр фічні проблеми укр їнського сел т 3 побігти виникненню демогр фічних к т строф у деяких регіон $\mathrm{x}$ кр їни необхідно з вдяки успішному економічному т соці льному реформув нню всіх скл дових гр рної сфери, що м тиме 3 г льний позитивний ефект для економіки держ ви. сновною метою реформи повинно бути подол ння бідності т безробіття в сільській місцевості. ерж ві доцільно виділяти більше коштів н поліпшення інфр структури в сільській місцевості, особливо тр нспортної т медичної.



ис. 5. ередній вік сільського н селення кр їни, 2015 р. (побудов но 3 [9])

Fig. 5. Average age of the rural population of Ukraine, 2015 (based on [9])

цьому контексті в жливо використ ти досвід ольщі, сільське н селення якої н період вступу до м ло подібні демогр фічні тенденції. ому держ в поч л проводити ктивну політику з подол ння бідності н селі. ирішув ли проблему ф ктичним звільненням селян від под тків. ольські селяни м ли спл чув ти спеці льний сільськогоспод рський под ток, який еквів лентний 3001000 грн з рік. кож було введено ефективну систему пенсійного з безпечення KRUS, згідно з якою місячний пенсійний збір з особи ст новить приблизно 20-50 злотих, тоді як у з г льній пенсійній системі ZUS це близько $20 \%$ місячного доходу. ольські селяни отрим ли безпроблемний доступ до сфери охорони здоров'я, причому т кож із символічними внеск ми до ерж вного медичного фонду, яких вист ч є н покриття лише 5-10 \% потреб [8].

економічному спекті в жливо ктивізув ти гробізнес в кр їні, сприяти розвитку фермерських господ рств. кож необхідно проводити політику підтримки прис диб- 
ного м лого господ рств ерж вне фін нсув ння освітніх прогр м з підготовки спеці лістів гр рної сфери т переробних г лузей, кредитув ння бізнесу й гр рного виробництв у сільській місцевості сприяли б появі робочих місць у сел х т посл били процеси ктивної мігр ції сільського н селення.

1. у удзеляк .. успільно-геогр фічні дослідження процесів н роджув ності в кр їні // кономічн т соці льн геогр фія. 2016. ип. 75. . 28-34.

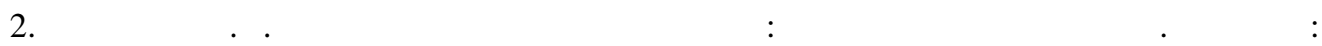
ут , 2003. 392 c.

3. сесоюзн я перепись н селения 1970 г. исленность сельского н селения союзных республик (кроме ) - жителей сельских н селенных пунктов - p йонных центров по полу // емоскоп weekly. [ лектронний ресурс]. ежим доступу: http://www.demoscope.ru/weekly/ssp/ussr70_reg3.php

4. сесоюзн я перепись н селения 1979 г. исленность городского н селения союзных республик, их территори льных единиц, городских поселений и городских р йонов по полу // емоскоп weekly. [ лектронний ресурс]. ежим доступу: http://demoscope.ru/weekly/ssp/rus79_reg1.php.

5. сесоюзн я перепись н селения 1989 г. исленность городского н селения союзных республик, их территори льных единиц, городских поселений и городских р йонов по полу // емоскоп weekly. [ лектронний ресурс]. ежим доступу: http://demoscope.ru/weekly/ssp/sng89_reg2.php

6. еогр фія олодомору $19321933 \mathrm{pp}$. // нститут демогр фії т соці льних досліджень. [ лектронний ресурс]. ежим доступу: http://tyzhden.ua/History/94477

7. овп $\kappa$. . еперспективні сел // нциклопедія історії кр їни. . 7: і- / едкол.: . . молій (голов ) т ін. кр їни. нститут історії кр їни. . : ук. думк , 2010. 728 с.: іл. [ лектронний ресурс]. ежим доступу: http://www.history.org.ua/?termin=Neperspektyvni_sela.

8. ог тько . . . ідність сільського н селення кр їни // емогр фія т соці льн економік . 2015. №1 (23). . 3243.

9. селення кр їни. нк д них // ерж вн служб ст тистики кр їни [ лектронний ресурс]. ежим доступу: http://database.ukrcensus.gov.ua/MULT/Dialog/statfile_c.asp

10. селення кр їни. оці льно-демогр фічні проблеми укр їнського сел ... н-т демогр фії т соці льних досліджень кр їни, 2007.

11. огожин . . емогр фічні перспективи укр їнського сел : історичні передумови, регіон льний н ліз, моделюв ння. .: н-т проблем н ціон льної безпеки, 2004.

12. озподіл постійного н селення 3 ст ттю т віком. т тистичний збірник. .: ерж вн служб ст тистики кр їни, 2015.

13. кр їн . гляд урб ніз ції. .: іжн родний $б$ нк реконструкції т розвитку / вітовий б нк, 2015. 195 с.

\section{REFERENCES}

1. Hudzelyak, I.I. (2016). Suspilno-heohrafichni doslidzhennya protsesiv narodzhuvanosti v Ukraini. Ekonomichna ta sotsialna heohrafiya, 75, 28-34 (in Ukrainian). 
2. Dzhaman, V.O. (2003). Rehionalni systemy rozselennia: demoheohrafichni aspecty. Chernivtsi: Ruta, 392 pp. (in Ukrainian).

3. Vsesoiuznaia perepys naselenyia $1970 \mathrm{~h}$. Chislennost' sel'skogo naselenija sojuznyh respublik (krome RSFSR) - zhitelej sel'skih naselennyh punktov - rajonnyh centrov po polu. Demoskop weekly. URL: http://demoscope.ru/weekly/ssp/rus79_reg1.php

4. Vsesoiuznaia perepys naselenyia $1979 \mathrm{~h}$. Chislennost' gorodskogo naselenija sojuznyh respublik, ih territorial'nyh edinic, gorodskih poselenij i gorodskih rajonov po polu. Demoskop weekly. URL: http://demoscope.ru/weekly/ssp/sng89_reg2.php

5. Vsesoiuznaia perepys naselenyia $1989 \mathrm{~h}$. Chislennost' gorodskogo naselenija sojuznyh respublik, ih territorial'nyh edinic, gorodskih poselenij i gorodskih rajonov po polu. Demoskop weekly. URL: http://www.demoscope.ru/weekly/ssp/ussr70_reg3.php

6. Instytut demohrafii ta sotsialnykh doslidzhen. Heohrafiia Holodomoru 1932-1933 rr., URL: http://tyzhden.ua/History/94477

7. Kovpak, L. V. (2010). Neperspektyvni sela. Entsyklopediia istorii Ukrainy, 7, 37 (in Ukrainian).

8. Kohatko, L. Yu. (2015). Bidnist silskoho naselennia Ukrainy. Demoghrafia ta sotsialna ekonomika, 1(23), 32-43 (in Ukrainian).

9. Derzhavna sluzhba statystyky Ukrainy. Naselennia Ukrainy. Bank danykh. URL: http://database.ukrcensus.gov.ua/MULT/Dialog/statfile_c.asp

10. Rohozhyn, O.H. (2014). Demohrafichni perspektyvy ukrainskoho sela: istorychni peredumovy, rehionalnyi analiz, modeliuvannia. Kyiv: Instytut problem natsionalnoi bezpeky, 269 pp. (in Ukrainian).

11. Rohozhyn, O.H. (2007). Naselenyia Ukrainy. Sotsialno-demohrafichni problemy ukrainskoho sela. Kyiv: Instytut demohrafii ta sotsialnykh doslidzhen NAN Ukrainy (in Ukrainian).

12. Derzhavna sluzba statystyky Ukrainy (2015). Statystychnyi zbirnyk. Rozpodil postiinoho naselennia za stattiu ta vikom. Kyiv, 348 pp. (in Ukrainian).

13. Ukraina. Ohliad urbanizatsii (2015). Kyiv. Miznarodnyi bank rekonstruktsii ta rozvytku. Svitovyi bank, 195 pp. (in Ukrainian).

m ття: н дійшл до ред кщї 14.10.2017

доопр иьов н 17.01 .2018

прийнят до друку 15.02.2018

\title{
DEMOGRAPHIC SITUATION IN RURAL LOCALITY OF UKRAINE: TRENDS AND REGIONAL FEATURES
}

\section{Iryna Hudzelyak, Iryna Dnistryanska}

\author{
Ivan Franko National University of Lviv, \\ P. Doroshenko St., 41, UA - 79007 Lviv, Ukraine, \\ e-mail: ihudzelyak@gmail.com,i.dnistrjanska@gmail.com
}

\footnotetext{
Ukrainian rural locality marks of negative demographic trends, which began to appear in most areas from the 1970-80s and primarily connected with depopulation processes. Forced industrialization and urbanization caused migratory outflow of rural residents that was additionally predetermined by liquidation policy of hamlets and "unpromising villages". It led to the exhaustion of the demographic
} 
potential, reduction in reproductive cohorts and to the aging population. Most acutely these trends were detected in Chernihiv, Sumy, Poltava, Zhytomyr and Kyiv regions, where a natural geography factors also didn't promote expansion of rural settlement network. Large negative impact on the reproduction of human potential was famine in 1932-1933. Depopulation of village people in Ukraine has taken place under the influence of unbalanced in spatial aspect social development. Namely, though stable underfunding there was a steady decline in health and education sector and in the other branches of social service completely did not meet the needs of modern society, which has lowered among young people the attractiveness of the villages as place permanent residence. Significant migration losses and lowering of the birth rate defined trends of rural population aging, faster than urban areas. Natural reproduction of rural population has a narrowed nature and is noted by gradual decline in the birth rate, which remains higher than in urban areas, mainly due to high mortality too distorted age structure. Natural and migration movement of the rural population defined the dynamics of the rural settlement network: reduced the number of settlements in almost all regions of Ukraine except Lviv, Ternopil, Ivano-Frankivsk, Chernivtsi, Volyn, Kherson and Zakarpattia region. The greatest reduction in the number of villages - in Poltava, Sumy, Chernihiv and Kirovohrad regions. Stabilization of depopulation processes in rural areas is possible implementation of social policies and activation of the processing industries related to the agricultural sector.

Key words: rural population, rural settlement, depopulation aging, natural reproduction, migration outflow. 